\title{
The future of the orphans: family and neighborhood networks and the choice of guardianship (northwest portugal in the eighteenth and nineteenth centuries)
}

\begin{abstract}
In the Ancien Régime the tutor was considered one of the most important figures of the trusteeship system, since he performed the duties of parents (administer, protect and sustain the orphans) although he was prohibited from certain acts, in particular, the sale of goods of minors. The legislation (judicial authorities) and the family of orphans controlled the tutor's liberty to administrate the assets. In addition, in case of mismanagement, responsibilities fell back entirely on the tutor, who should respond with his own possessions. In resume, the law sought to avoid the mismanagement of the orphan's wealth. Therefore, if one was not a tutor because the law prevented them, in particular the mother and in certain situations the older brothers of age were. Other individuals were not because they refused, presenting a varied number of arguments. However, from the second quarter of the nineteenth century the Portuguese legislation has undergone changes in these matters in order to overcome the bureaucracy behind the defense, especially the exerted by mothers and put an end to abuses. In this way, we have seen the creation of the Council of the Family who had underlying a set of functions, among which, controlling the tutor in the exercise of guardianship of orphans, absent heirs and impaired.
\end{abstract}

Keywords: orphan inventories, wills, orphans, tutor, council of the family, eighteenth and nineteenth centuries
Volume 3 Issue 3 - 2018

\author{
Olanda Vilaça \\ Doctor, Department of Modern History, University of the \\ Minho, Portugal
}

Correspondence: Olanda Vilaça, Doctor, Department of Modern History, University of the Minho, Portugal, Tel 2539 53049, Email olanda.vilaca@gmail.com

Received: August 28, 2018 | Published: May 25, 2018

\section{Introduction}

This study will be sustained using as main sources the orphan inventories (600) and annexing last wills of three municipalities (Barcelos, Guimarães and Póvoa de Lanhoso) of Baixo Minho, between 1750-1850 (Figure 1). ${ }^{1}$

Through the orphan inventories it was intended that all the heirs had access to part of the inheritance that was his by right, in other words, legitima (share of the inheritance ascribed by laws of succession), avoiding, in this way, that the least able to administer their goods were object of usurpation on the part of those who were in a position to do so. The death of parents or other relatives to whom the orphans belonged to made them legitimate heirs. For that reason, the inventory process had to be immediately opened so that the property of inheritance could be inventoried, evaluated and divided. In this process, as we shall see, was very important the role played by tutor or curator. ${ }^{2}$

According to Rafael Bluteau, tutor and curator differ in three points. Let's see: the tutor first treats the person that was under their guardianship, secondly their farm and, finally, of his heritage. ${ }^{3}$ The

\footnotetext{
${ }^{1} \mathrm{~A}$ part of this work was aborded in our doctoral thesis. Material culture and heritage assets in the rural world of the Baixo Minho - Nw Portugal, 17501810, Braga, Universidade do Minho, 2012, pp. 23-29.

${ }^{2}$ António de Moraes Silva, Novo dicionário compacto da língua portuguesa, vol. II, Lisboa, Editorial Confluência, 1813, p. 195

${ }^{3}$ By farm, we understood "riches and money". Rafael Bluteau, Vocabulário português e latino..., vol. IV, Coimbra, Colégio das Artes da Companhia de Jesus, 1712-1728, p. 48. Heritage, are the property left by parents and that will
}

curator first treats the farm and only after the person; the underage boy or girl were assigned to a tutor, an adult or impaired curator, who was merely appointed to provide a service. The judge generally appointed the tutor with this function. However, the person granted by the tester in the testament, even if against their will, he may not willingly accept this function. ${ }^{4}$ In sum, the tutor was considered to be one of the most important figures of the trusteeship system, since he performed the duties of parents (administer, protect and sustain the orphans) although he was prohibited from certain acts, in particular, the sale of goods of minors. The curator was judicially responsible to administer or supervise the property of someone in special conditions. ${ }^{5}$ Nevertheless, the process of tutelage started with the registrar of orphans, who under the direction of the judge of orphans informed them of the executrix to appoint a tutor. ${ }^{6}$ In the eighteenth century, the Portuguese law established that when the father became a widower, he was automatically constituted the legitimate administrator of his children. In this case, he should preserve the children's assets while they were minor (for example, he was not allowed to sell property). be inherited by members of the same family. Idem, vol. VI, 1712-1728, p. 322 ${ }^{4}$ Idem, vol. II, 1712-1728, p. 640. The Council of the Family was created in 1832, to oversee the assets of the orphans. Maria de Fátima Brandão, Terra, herança e família no noroeste de Portugal: o caso de Mosteiro no século XIX, Porto, Afrontamento, 1994, p. 329.

${ }^{5}$ Olanda Barbosa Vilaça, "Podemos conhecer os patrimónios móveis através dos inventários orfanológicos? Os casos de Guimarães e Barcelos (séculos XVIII-XIX)”, in Isabel dos Guimarães Sá, Máximo García Fernández (dir.), Portas adentro: comer, vestir, habitar (ss. XVI-XIX), Valladolid, Universidad de Valladolid, Imprensa da Universidade de Coimbra, 2010, pp. 238-239

${ }^{6}$ Codigo Philippino ou Ordenações e Leis do Reino de Portugal, Liv. IV, Tít. LXVIII, fl. 147 
While children were not at the age of 25 years or emancipated (it could be obtained by royal permission, through a Carta Régia de Emancipação; means to be capable to manage their own patrimony), the father was only allowed to spend the rest of the immovable properties. In case of the deceased father, the executrix was notified to choose a tutor for the children. The relatives were the first to be called, since the judge of the orphans had the precaution to appoint the nearest, the most qualified and wealthy relative to be the tutor. When there were no close relatives, the judge chose other person and only in case there were no close relatives, the judge elected one of the neighbors. If the executrix was the mother and if she wanted to be the tutor, she had to require a provision from the Desembargo do Paço. In this provision, the widow pledged to sustain, to dress and to indoctrinate the children with their own resources, to deliver to the children the income of their legitimas in full when they marry or if emancipate or if the executrix (a widow) will get married; finally, before a favorable sentence, the widow, was obligated to submit a suitable and wealthy guarantor, in order to take responsibility for any loss or damage that this would jeopardize the incomes of legítimas of their children. ${ }^{1-5}$

This request was not always pleased. In this society, women were, most of the time, considered fragile and unable to take responsibilities towards children. In fact, quite few were recognized as able to do so. In most of the cases, when women were chosen to be tutors it was through their husband's testament, where he expressly indicated his wife to be the administrator and tutor of the children. This issue legal and procedural was applied throughout the Kingdom. In this way, initially, we have tried answer a question. What would be the nature of the tutelage/guardianship accorded to widows of the Baixo Minho? The tables that follow have sought, in a first phase, to ascertain the gender of inventoried only using orphan inventories. Then, based on the results obtained, we have directed our analysis in a single direction: the inventoried married male. Our aim was to determine the number of widows who managed the tutelage of their children as well as the origin of tutelage, whether by legal provision or by testamentary appointment. For this reason, we crossed the information of orphan inventories with the testament (Table 1)(Table 2).

Table 1 The gender of inventoried (1750 - 1810)

\begin{tabular}{lllll}
\hline Municipalities & Man & Woman & Mixed & Total \\
\hline Póvoa de Lanhoso & 115 & 70 & 15 & 200 \\
& $57.50 \%$ & $35 \%$ & $7.50 \%$ & $100 \%$ \\
Barcelos & 104 & 81 & 15 & 200 \\
& $52 \%$ & $40.50 \%$ & $7.50 \%$ & $100 \%$ \\
Guimarães & 101 & 84 & 14 & 200 \\
& $51 \%$ & $42 \%$ & $7 \%$ & $100 \%$ \\
\hline
\end{tabular}

Table 2 Marital status of male inventoried

\begin{tabular}{llll}
\hline Municipalities & Single & Married & Widower \\
\hline Póvoa de & 5 & 95 & 15 \\
& $4.40 \%$ & $82.60 \%$ & $13 \%$ \\
Lanhoso & 1 & 68 & 35 \\
Barcelos & $1 \%$ & $65.40 \%$ & $33.60 \%$ \\
Guimarães & 6 & 77 & 17 \\
\hline
\end{tabular}

Table 3 Nature of tutelage of widows inventoried

\begin{tabular}{llll}
\hline Municipalities & $\begin{array}{l}\text { Tutelage } \\
\text { Provision }\end{array}$ & $\begin{array}{l}\text { Appointment } \\
\text { will }\end{array}$ & Total \\
\hline Póvoa de Lanhoso & 6 & 4 & 10 \\
& $6,3 \%$ & $4,2 \%$ & $10,5 \%$ \\
Barcelos & 14 & 3 & 17 \\
& $20,6 \%$ & $4,4 \%$ & $25 \%$ \\
Guimarães & 22 & 8 & 30 \\
& $28,6 \%$ & $10,4 \%$ & $39 \%$
\end{tabular}

Note: Arquivo Distrital de Braga and Arquivo Municipal Alfredo Pimenta (hereby ADB and AMAP), "Judicial Antigo".

In Table $3^{7}$ we have confirmed that it is not always the widow, executrix and couple head, took the tutelage of their children. Let's see: in the municipality of Póvoa de Lanhoso only $10.5 \%$ of widows took the guardianship, of which $6.3 \%$ through provision of tutelage and $4.2 \%$ for having been named tutors and administrators of their children in testament; in the municipality of Barcelos, $25 \%$ of widows took the guardianship, of which $20.6 \%$ by provision of tutelage and $4.4 \%$ by appointment at testament; in Guimarães municipality, the number of widows who took the tutelage was more expressive, $39 \%$, of which $28.6 \%$ by provision of tutelage and $10.4 \%$ by appointment in testament. There is no doubt that a significant number of women widows demanded their right to guardianship and the administration of the goods of their children; others were recognized as able to do so by your spouse still living. In fact, when the father became widower, he was automatically as legitimate administrator of the orphans, although with the exception of maintaining the goods as the property, while you reserved the right to spend only the rents and "news" hole of goods while the orphans were under its guardianship. ${ }^{8}$ If it were necessary to recourse to the sale of goods, the tutor would have to request permission to the judge of the orphans. In our sample, this situation happened not with a tutor but with an orphan. In the José Antunes Rocha inventory, died in the October 18th, 1784, of the village of Fontarcada, Póvoa de Lanhoso, after the reports taken the tutor Domingos Francisco, nearest neighbor, the orphan Manuel, for 19 years, stated that: "You're old enough to learn the trade of carpenter but he needs the permission of the judge and of the tutor, since that is the only way that he could buy the tools needed for the trade" Neither the tutor nor the orphans could use the legítima without the consent of the judge of the orphans. However, the orphan was subject not only to this last mentioned as well as tutor. In our documentation we found three distinct types of tutor: the most common, the tutor legitimate or dative, appointed by executrix, which assumes the guardianship until the orphans reach adulthood or even their emancipation. The infactum or interino tutor (interim) performed the function only for the purpose of sharing while the tutor appointed did not perform of the sworn. And, generally, was whether interino tutor - a term used with greater frequency in our sample-, when the widow asked for the provision of tutelage or even when one of the brothers (higher of age) of the

\footnotetext{
${ }^{7}$ The number of married men in table 2 balances the "Total" item in the table 3 ${ }^{8}$ news" - the same as fruits. In the Ancien Régime, the slaves as the same denomination. Codigo Philippino ou Ordenações e Leis do Reino de Portugal, Liv. IV, Tít. LXXXVIII, Rio Janeiro, edição de Cândido Mendes de Almeida, 1870, p. 209. Disponível online em http://www.iuslusitaniae.fcsh.unl.pt/ verobra.php?id_obra $=65$

${ }^{9}$ ADB, "Judicial Antigo", Póvoa de Lanhoso, ct. 2838, 1784, fl. 28v
} 
orphan's minors was appointed by the mother as a tutor in testament. The interino tutor exercised this function until the time of the grant of the provision of tutelage by Desembargo do Paço to the requesting and respective sworn. ${ }^{5-10}$

By the way, in the Manuel José de Carvalho inventory, of the village of St. Estevão of Geraz, termo (hinterland) of Póvoa de Lanhoso, was appointed a interino tutor because the widow, Ondina Maria Carvalho, executrix, having required tutelage presented a term of warrantor, but ended the inventory had not yet received the respective provision, thus unable to assume the guardianship and the administration. ${ }^{10}$ We have finally the wills tutor, appointed in testament. In the case of the tester appoint his wife as a tutor and administrator of their children, according to the law, this was not obliged to present warrantor. However, the appointment must be confirmed by the royal administration. Although it was not necessary to presented warrantor, as mentioned, there have been cases such as, for example, in the João Francisco Xavier inventory, in which the widow executrix, Maria Josefa da Cruz, testamentary tutor, made a point of requesting, for their protection, provision of tutelage appointing, for a limited period, to tutor their minor children a close relatives, Manuel Antunes, wealthy farmer. ${ }^{11}$

The relatives were the first to be called, since the judge of the orphans had the precaution to appoint the nearest, the most qualified and wealthy relative to be the tutor. When there were no close relatives, the judge chose other person and only in case there were no close relatives, the judge elected one of the neighbors. If some were not tutors because the law prevented them, specifically the mother and, in some situations, the older brothers, others were not because they refused, presenting arguments such as sickness and were not relatives, friends or neighbors. Furthermore, those who were privileged of the Holy Trinity and those who were municipal officers were free to assume the custody, so, whenever they could, they used these arguments to waive the responsibility. Many of the appointed tutors refused, even when it was paid. The tutor, regardless of the nature of the custody, was paid with an annual salary called, in Portuguese, vintena. This corresponded to $20 \%$ of the income that was under custody. However, in any case, this value could not exceed the 50.000 réis (current coin in the eighteenth century in Portugal) per year. ${ }^{12}$ The curator, unlike the tutor, had no right to vintena but a salary that varied from region to region.

\section{Why some tutors refused the position?}

After the judge of the orphans deliberated the custody, the tutor was asked to provide all relevant information to draw up the inventory of all assets. However, his role did not end here. After the inventory, which included the assessment and the division of the property, the tutor had to guarantee the protection and education of the children until they reached adulthood. In concern to the administration, the Portuguese law stated that the tutor was required to present prove of the incomes and expenses to the judge each triennium. This should contain a description of all costs and incomes of those who were under custody. Moreover, if it was necessary to sell any part of the patrimony, the tutor should ask permission to the judge. The legislation controlled the tutor's liberty to administrate the assets. In addition, in case of

${ }^{10}$ Idem, Póvoa de Lanhoso, ct. 508, 1804, fl. 11.

${ }^{11}$ Idem, ct. 2693, 1777, fl. 20v.

${ }^{12}$ António Joaquim Ferreira D'Eça e Leiva, Memorias theoricas e practicas do Direito Orphanologico, $3^{\text {a }}$ ed., Porto, Jacintho Antonio Pinto da Silva, s/d, p. 99; Cândido Mendes de Almeida, ob. cit., 1870, p. 219. mismanagement, responsibilities fell back entirely on the tutor, who should respond with his own possessions. In resume, the law prevented to avoid the mismanagement of the orphan's wealth. Some tutors ended up resigning, as it was the case of Bento José de Araújo. $\mathrm{He}$ was tutor for eight years and after that period he asked to be dismissed because "there were other richer relatives". ${ }^{13}$ In addition to the judicial authorities, the relatives, especially the widow, conscious of the tutor responsibilities, launched a fierce look on how the tutor ran the children's assets. For example, Francisca Teresa, executrix, widow who lived in Póvoa de Lanhoso, dismissed the paternal grandfather of the minors, António da Silva, accusing him for "selling the cattle and spending money on things that was not related to the children". ${ }^{14}$ In this situation, there was a second appointment that fell on Jerónimo da Silva, brother of the deceased. ${ }^{11-14}$

Given this set of restrictions it is understandable the efforts to revoke the custody. The nominees, aware of the responsibilities, argued, whenever they could, with their offices, or asserted the existence of closest and wealthiest relatives or even invoked advanced age. The courts did not always consider these reasons valid. Tutors were forced to accept the position otherwise their goods could be confiscated or could be arrested. ${ }^{15}$ In resume, considering the tutor obligations and how they were observed either by family, as well as by the judicial authorities, this position was undoubtedly a burden that many have tried to escape, through the law interstices. In the second quarter of the nineteenth century the Portuguese legislation has undergone major changes to respect those who tutelary underaged children, impaired and absent heirs. The goal was to simplify the bureaucracy of tutelage, especially those which would be exercised by the mother that should replace the "agents of the government that many rare times they want the orphans' something that is not the money, by a council of relatives and other persons more arrivals to minors protected", such as stresses Maria de Fátima Brandão. ${ }^{16}$ In this way, the law of may 18th, 1832 (art. ${ }^{\circ} 1$ ), in addition to dismissing the judges of the orphans by replacing them by judges of the peace and giving them skills in several judicial matters (orphan inventories, guardianship and emancipations), created the Council of the Family to supervise the property of the orphans. ${ }^{17}$ The executrix appointed this new component. ${ }^{18}$ It should also be pointed out that, throughout

\footnotetext{
${ }^{13}$ ADB, "Judicial Antigo", Póvoa de Lanhoso, ct. 624, 1791, fl. 22.

${ }^{14}$ Idem, ct. 284,1808 , fl. $3 \mathrm{v}$

${ }^{15}$ Idem, ct. 2798, 1766, fl. 14v; Idem, ct. 624, 1791 fl. 22 Cândido Mendes de Almeida, ob. cit., Liv. I, Tit. LXXXVIII, 1870, p. 210.
}

${ }^{16}$ Maria de Fátima Brandão, ob. cit., 1994, p. 328; Novíssima reforma judiciaria ou decreto de de Novembro de 1840 e decreto de 21 de Maio de 1841, Lisboa: Typographia de Barbosa, 1841, art. $^{\circ}$ 404. This new reform was very important to the establishment of an institutionalized system and systematic of popular participation in the administration of justice", as stresses José António Barreiros, especially regarding the judge of the peace, who was elected by the people José António Barreiros, "As instituições criminais em Portugal no século XIX: subsídios para a sua história", in Análise Social, vol. XVI (63), 1980, 3..$^{\circ}$, p. 601.

${ }^{17}$ The judge of the orphan office was created in the fourteenth century to respond the high demographic weight of the orphans. Ana Isabel Marques Guedes, Os colégios dos meninos órfãos (sécs. XVII-XIX), Évora, Porto e Braga, Lisboa, Imprensa de Ciências Sociais, 2006, pp. 26-28.

${ }^{18}$ Decreto de 18 de Maio - Jurisprudência relativa a órfãos", in Collecção de Decretos e Regulamentos Mandados Publicar por sua Majestade Imperial o Regente do Reino desde que Assumiu a Regência em 3 de Março até à sua Entrada em Lisboa em 28 de Julho de 1833, 2. a série, Lisboa, Imprensa Nacional, 1836. José António Barreiros, ob. cit., 1980, p.591. 
the eighteenth century until the new judicial organization of the Country, 1832-1835, ${ }^{19}$ the Judge of the orphans only existed in towns or hinterland that they had more than four hundred neighbors and upward..$^{20}$ In other localities, the protection of orphans was entrusted to Judge of "Fora" (out), or until the judge ordinary assisted by notary public. With the new organization, the villages have their own judges of the peace. ${ }^{21}$ We have seen this change in inventories consulted. Let's see: in the António Vilar inventory, the village of S. Bartolomeu, municipality of Póvoa de Lanhoso, is explicit that the judge of peace and of the orphans had jurisdiction in three villages. Let's look at an example: "Year of the birth of our Lord Jesus Christ in the year one thousand eight hundred and thirty-five years, the four days of the month of December of that year, in the house of Carreira that is the home of João Batista da Cruz, judge of peace and the orphans of this village of Brunhais, S. Bartolomeu and Soutelo (...) ".22

Nevertheless, there have been cases in which the judge of the peace exercised jurisdiction only in a village and in other cases, more frequent in two villages. Relatively the Council of the Family, let's see: the registrar of the orphans, at the request of the Judge of peace and of the orphans, informing the executrix for appoint between the relatives and friendly neighbors that should compose the Council of the Family. Four members of the male gender should compose the Council. In other words, the composition of the Council of the Family followed in the order established by law: four relatives of the orphans, residing in the same jurisdiction; the consanguinity passed over the affinity and the men to women; in the same degree of kinship, the older passed over new ones. In the absence of relatives, the executrix could appoint friends and/or the "good men of the village". ${ }^{23}$

The orphan inventories should begin by the invocation of the Council of the Family. Later, it was the duties of the Council of the Family appoint the tutor, the sub-tutor, the curator and the louvados (men responsible for the assessment of property). As can be seen, with the reforms undertaken in the nineteenth century has seen the emergence of a new figure, the sub-tutor, which was requested, as is clear in the inventories, "which look after the property of its people, as well as managing their assets, while ensuring as own the interests of same (orphans) and looking for all its justice and right everything under the greater responsibility in accordance of the Laws" ${ }^{24}$ It is assumed that the sub-tutor would assist the tutor. However, the creation of this office has raised an issue. Will the office of sub-tutor had not created, also, to supervise the guardianship on the need to safeguard the assets of orphans? In fact, in terms of tutelage and subtutelage listed in the orphan inventories of Barcelos, verifies that there is no distinction between one and another office (tutor and sub-tutor). Nevertheless, thinking of the word sub-tutor contains the prefix of

${ }^{19}$ Mouzinho da Silveira, Silva Carvalho and others performed the new judicial system. Maria de Fátima Brandão, Rui Graça Feijó, "O discurso reformador de Mouzinho da Silveira", in Análise Social, vol. XVI (61-62), 1980 - 1. ${ }^{\circ}$ - 2. o, p. 238.

${ }^{20}$ Codigo Philipino ou Ordenações e Leis do Reino do Portugal, 1870, Liv. I, Tit. LXXXVIII, $p$.

${ }^{21}$ A. H. Oliveira Marques, História de Portugal - Desde os tempos mais antigos até ao governo do Sr. Pinheiro de Azevedo, vol. II, 1. ${ }^{a}$ Ed., Palas Editores, Lisboa, 1974, p. 28.

${ }^{22}$ ADB, Póvoa de Lanhoso, ct. 3403, 1835, fl. 2.

${ }^{23}$ José Dias Ferreira (anot.), Codigo Civil Portuguez, Lisboa, Imprensa Nacional, 1870-1876. Disponível em http://purl.pt/12145

${ }^{24}$ ADB, Barcelos, ct. 3029, 1836, fl. 3v. inferiority it follows that this should exercise an action more moderate when compared with the tutor. Implicitly, the Ancien

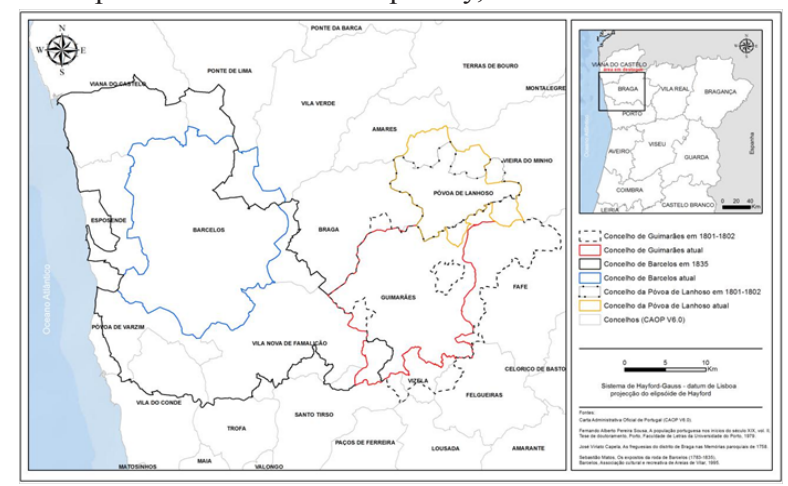

Figure 1 Map of geographical environment.

Régime to the Contemporaneity there was an alteration with regard to the guardianship. This position came to be exercised not by one but by two people. Appointed by the members of the Council of the Family, these people were considered good reputation and able to exercise the powers with they were conferred. As in the eighteenth century, the relatives more arrivals were the first to be called to assume either the tutelage or the sub-tutelage. In this new legislative framework would have a widow, mother of the orphans, the life easier to assume the tutelage and assert itself as legitimate administratrix of their children as to their persons and properties? According to the Civil Code, the mothers started, as parents, to be considered natural tutors. ${ }^{25}$ Going to meet the new ideals, the legislative framework has determined that "The civil law is equal for all, it makes no distinction of person or sex..." ${ }^{26}$ However, in practice, on daily, the ability of women to take over the guardianship and administer the assets of the orphans and absent continued to be regarded as inferior when compared with that of their husbands..$^{27}$ They assumed the tutelage in a natural way while widows only has access to the tutelage, as in the Ancien Régime, through scriptures of the wills and provisions of tutelage. However, during the period in question, such as the appointment of the tutor was the responsibility of members of the Council of the Family and the appointment of these was the responsibility of the executrix, in general the widow. Thus, we can say that the widow had the freedom to choose/appoint among people who were part of their social and affective relations, which, in principle, decided in her favor regarding to the guardianship, tutelage. In the transcribed inventories, relatively to the second quarter of the nineteenth century, it was observed that, without exception, the Council of the Family opted to appoint a tutor for the orphans the executrix widow. Thus, we can conclude that the guardianship was more accessible to the widows. However, the pursuit of the same has become more difficult. With the presence of a sub-tutor and of the Council of the Family, the control of the guardianship would be tougher.

We can find an example of the severed control exercised by the Council of the Family in the Antonia Rita inventory open upon the death of her husband. Having been appointed tutor, later the Council

\footnotetext{
${ }^{25}$ Maria de Fátima Brandão, ob. cit., 1994, p. 327.

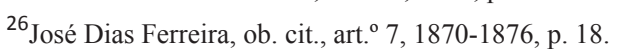

${ }^{27}$ Maria de Fátima Brandão points out that husbands, still living, could nominate two people to "guide and counsel the widow", limiting, in a subtle way, the powers of guardianship. Maria de Fátima Brandão, ob. cit., 1994, p. 328 . 
of the Family asked her dismissal for having donated the house that had one of her daughters, harming the remaining heirs. We will see: "In the year of the birth of our Lord Jesus Christ in the year one thousand eight hundred and thirty-nine years, the twenty-six days in the month of February in this village of Brunhais and houses of the dwelling place of Antonio Gonçalves de Sousa, judge of the peace. This district attended this Domingos de Oliveira and Castro, Manoel de Matos Guimaraes and Manoel José de Carvalho all of the village of S. Bartolomeu, members of the Council of the Family in this inventory and for them it was said that as the tutor executrix made donation of his house to his daughter Teresa to marry as married with Francisco Manuel Carneiro. Making it without means to continue under the tutelage of their children so they dissolving this tutelage and nominated to tutor the same Francisco Manuel Carneiro (son-in-law) to which taking sworn to be able to interest the ranges of incomes and expensive retro with the collateral needed worth responding by future interest". ${ }^{28}$

Likely, as the tutor donated the property, the house, his son-inlaw and daughter, let us be clear, the only property that guarantee the payment of any loss that could arise from a poor administration of guardianship, the Council of the Family dismissed it and appointed tutor of minors the own son-in-law, thus ensuring the safeguarding of the assets of the orphans. Regarding the procedures carried out by the Council of the Family to the sharing of the heritage of heirs, we will mention only just one aspect that we consider relevant. In the Ancien Régime, the division of property was the responsibility of partidores (partitioner), which proceeded to the division/distribution of goods, based on the principle of equality between the heirs. In transcripts Inventories of the second quarter of the nineteenth century we have observed some very curious procedures that underline the said principle of equality between the heirs. Let's see. After the deliberate purpose of the inventory, the registrar on behalf of the Judge of the peace was notifying the Council of the Family and other interested parties, such as the curator, the executrix, the tutor, the sub-tutor and the other heirs, to proceed to the shares in accordance with the provisions outlined presented throughout of the inventory. If everyone to accept the determination of sharing they proceeded to constitution of quinhões (lots) called montes (mount), of equal value. Then they proceeded to sorteamento (to cast lots). ${ }^{29}$

To this end, the Council of the Family used two runs and two sets of tickets, one with the name of the heirs and another with the letters of the alphabet that corresponded to the lots that formed the heritage. For instance: in the José Luis de Matos inventory, of the village of Esperança, Póvoa de Lanhoso, was seven children, six of them minors. For the sharing, were placed seven tickets identified by the letters A, $\mathrm{B}, \mathrm{C}, \mathrm{D}, \mathrm{E}, \mathrm{F}, \mathrm{G}$ within an urn that corresponded to the lots to share. And, seven more tickets with the name of each heir placed in another urn. The tutor got a ticket, by luck, the urn with the identification of the mountains and the curator got a ticket, by luck, the urn with the identification of heirs. As the two were taking a ticket at the same time, they delivered them to the judge of peace and the orphans. It was thus defined the lots that each heir would be entitled. ${ }^{30}$ This process

\footnotetext{
${ }^{28}$ ADB, Póvoa de Lanhoso, ct. 2529, 1839

${ }^{29}$ Maria de Fátima Brandão concerning Vieira do Minho observed the same. Maria de Fátima Brandão, ob. cit., 1994, p. 139.

${ }^{30} \mathrm{ADB}$, Póvoa de Lanhoso, ct. 2529, 1833.
}

was called "Publicação e sorteamento". In our view, the sorteamento brought more consistency and justice to the inheritance process. Thus, could prevent deflation or inflation of property appraisals by louvados for the benefit of any heir. Besides, it should be noted that with this procedure the gender differentiation manifested in the composition of the lots observed by us in the inventories of the municipalities of Barcelos, Guimarães and Póvoa de Lanhoso on the second half of the eighteenth century is no longer feasible. ${ }^{31}$ For this reason, we believe that the sorteamento of lots gave to the sharing greater equality and justice among the heirs.

Finally, it is important to make reference to the expenses and income of the orphans, impaired and absent heirs that the tutor would have to submit to the Council of the Family. This component chose and appointed, according to the art. ${ }^{\circ} 55$ of law twenty-six may 16 , 1832 , two of its members to examine the expenditure and income, approving them in accordance with the provisions outlined. However, if there was any suspicion, the Council of the Family required the annual presentation of the reports to the tutor. It should be noted that the tutor and executrix, if it existed, should present that. For example, in the António Joaquim Borges inventory, of the village of Cossourado, Barcelos, the Council of the Family ask to be taken the reports of the tutor and the executor, grandfather of minors, because both protected the orphans and their property. ${ }^{32}$ Thus, in this field also saw some changes. In the Ancien Régime the reports taken to the tutor were presented to the Judge of the orphans that analyzed and approved. In the Contemporary period the judge of the peace doesn't intervene. This function is the responsibility of the Council of the Family, which, in turn, chose and appointed two elements to examine thoroughly all expenditure and income of those who were under the guardianship. Only in the last case the Council of the Family called the higher courts.

\section{Conclusion}

It can be concluded that the Council of the Family, after the Civil Code has played a vital important role in safeguarding the assets of the orphans and of its persons. In fact, the Council of the Family had many functions: appoint or dismiss the tutor and sub-tutor, oversee its functions, both at the level of the administration of property of the orphans, of its persons; the integration of these in the professional world; and also appoint the louvados. However, the deliberations of the Council of the Family in respect of assets or liabilities loans, accept or reject inheritance, examinations of reports of guardianship, sale, exchange or alienation of goods, leases for more than three years, should be taken with the audience of the curator and the approval of the Judge of Law. ${ }^{33}$ This means that the Council of the Family, as the tutor of the eighteenth century, did not have complete freedom regarding to the administration of property of the orphans, impaired and absent heirs. In sum, the preservation of property of the orphans who are minor, impaired and absent was always a subject that has aroused the attention of lawyers in the family history. The various changes in the law over the eighteenth and nineteenth centuries testify to the importance of supervision of those who had responsibility

\footnotetext{
${ }^{31}$ Olanda Barbosa Vilaça, ob. cit., 2012, p. 33.

${ }^{32}$ ADB, Barcelos, ct. 3929, 1836.

${ }^{33}$ Novíssima reforma judiciaria ou decreto de 28 de Novembro de 1840 e decreto de 21 de Maio de 1841, art. $^{\circ} 396$.
} 
for the administration of the assets of these people as well as their education until they reach the adulthood age.

\section{Acknowledgements}

None.

\section{Conflict of interest}

Author declares that there is no conflict of interest.

\section{References}

1. Barreiros JA. As instituições criminais em Portugal no século XIX: subsídios para a sua história. Análise Social. 1980;16(63):587-612.

2. Bluteau R. Vocabulário português e latino, Coimbra vol II \& IV. Colégio das Artes da Companhia de Jesus; 1712-1728.

3. Brandão FBT. herança e família no noroeste de Portugal: o caso do Mosteiro no século XIX. Porto: Afrontamento; 1994.

4. Brandão MF, Feijó RG. O discurso reformador de Mouzinho da Silveira. Análise Social. 1980;16(61-62):237-258.

5. Codigo Philippino ou Ordenações e Leis do Reino de Portugal. Rio Janeiro: Edição de Cândido Mendes de Almeida, 1870.

6. Jurisprudência relativa a órfãos. Collecção de Decretos e Regulamentos Mandados Publicar por sua Majestade Imperial o Regente do Reino desde Que Assumiu a Regência em 3 de Março até à sua Entrada em Lisboa em 28 de Julho de 1833, 2ª série. Lisboa: Imprensa Nacional; 1836.
7. Ferreira JD. Codigo Civil Portuguez, Lisboa. Imprensa Nacional. 1870.

8. Guedes AIM. Os colégios dos meninos órfãos (sécs. XVII-XIX). Imprensa de Ciências Sociais. 2009;44(1):274.

9. Leiva AJF. Memorias theoricas e practicas do Direito Orphanologico $3^{a}$ ed. Porto: Jacintho Antonio Pinto da Silva.

10. Marques AHO. História de Portugal-Desde os tempos mais antigos até ao governo do Sr. Pinheiro de Azevedo vol II, $1^{a}$ ed. Lisboa: Palas Editores; 1974.

11. Novissima reforma judiciaria ou decreto de 28 de Novembro de 1840 e decreto de 21 de Maio de 1841. Lisboa: Typographia de Barbosa; 1841. p. 396,404 .

12. Silva AM. Novo dicionário compacto da língua portuguesa vol II. Lisboa: Editorial Confluência; 1813.

13. Vilaça OB. Podemos conhecer os patrimónios móveis através dos inventários orfanológicos? Os casos de Guimarães e Barcelos (séculos XVIII-XIX). Imprensa da Universidade de Coimbra. 2010;237-250.

14. Vilaça OB. Cultura Material e património móvel no mundo rural do Baixo Minho em finais do Antigo Regime. Universidade do Minho. 2012. 